\title{
The Effect of Cooperative Integrated Reading and Composition (CIRC) Learning Models Flash Media Assisted on Bahasa Learning Outcomes in Grade V Primary School
}

\author{
E.B.Simanjuntak ${ }^{1 *}$, N.Simbolon ${ }^{1}$, S.Murni A. ${ }^{1}$, Situmorang $^{1}$, I.Harun $^{1}$ \\ \{* evabettysimanjuntak@yahoo.co.id \} \\ ${ }^{1}$ Faculty of Education, State University of Medan, Medan, North Sumatra, Indonesia
}

\begin{abstract}
The Effect OfCoopertative Integrated ReadingAnd Composition (Circ) Learning Models Flash Media Assisted on Bahasa Learning Outcomes InGrade V Primary School. This research aims to see the effect of using Cooperative Integrated Reading and Composition (Circ) Learning Models Flash Media Assisted On Bahasa Learning Outcomes In Grade V State Primary School 101776 Sampali.The technique of hypothesis testing is done using t-Test. On the pretest data normality test with the provisions Lcount $<$ Ltable $=0,161<0,173$ in the control class, while the experimental class $=0.154<0.173$ so that it can be stated that the two groups of samples are normally distributed. In the normality test the postest data is known Lcount $<$ Ltable $=0,167<0,173$ in the control class, while the experimental class $=0,150<0,173$ so that the data is normally distributed. In testing the homogeneity of the pretest data is known by the provisions Fcount $<$ Ftable $=1,228<1,983$, and the data homogeneity of postest $=1.178<$ 1.983 so that it can be concluded that the two groups of data have the same variance. Then a t-test is performed with a significant level of $5 \%$ which shows that there is a significant influence on learning using the Coopertative Integrated Reading and Composition (Circ) Learning Models in Bahasa subject to poetry writing skills of students of Grade V State Primary School 101776 Sampali 2017/2018 Academic Year withtcount $>$ ttable $=(3,317>2,012)$. So it can be concluded that there is a significant influence on the use of Cooperative Integrated Reading And Composition (Circ) Learning Models Flash Media Assisted On Bahasa Learning Outcomes In Grade V State Primary School 101776 Sampali 2017/2018 Academic Year.
\end{abstract}

Keywords: CIRC learning models flash media assisted, bahasa

\section{Introduction}

In essence, education aims to humanize humans (humanization) and develop the potential that exists within humans themselves. education is a form of implementation of a goal that a country wants to achieve. And one indicator of the implementation of education is through the learning process in schools and universities. So, education is closely related to learning.

Learning also will not stay away from objects that will be taught, namely students. Basically, students are social beings, so there must be interaction and communication with other students. Regarding the statement above, to form competent students in various fields, 
the role of language has a big role in it, because language is an important communication tool in everyday life.

Ideally to harmonize the quality of education requires innovation in the learning process. In fact, in Indonesia innovation in the learning process is still less than optimal. One of them is in Public Primary School 101776 Sampali. The learning system should be more advanced than the previous era. One way to anticipate the innovation of learning by utilizing learning models and technology-based learning media as a tool for teaching and learning. At present technology has become part of human life that is able to facilitate the survival of humans, as well as in education. The use of learning media can save teaching preparation time, increase student learning motivation and reduce students' misunderstanding of the explanations given by the teacher. The policy on the use of Information and Communication Technology is contained in the Republic of Indonesia Minister of Education and Culture Regulation (Permendikbud) Number 65 of 2013a concerning Standard and Secondary Education Process Standards in paragraph 13, namely "the use of information and communication technology to improve the efficiency and effectiveness of learning".

Based on observations at Public Primary School 101776 Sampali conducted by researchers, showed that V-A class with a total of 25 students consisted of 15 male students and 10 female students and V-B class with a total of 25 students consisting of 17 male students and 8 female students, from 50 students in class V-A and V-B only $30 \%$ of students who get grades $>70$ while $70 \%$ of other students get a score of $<70-40$, this shows that only $30 \%$ of 50 students who are able to achieve the minimum completeness criteria are at a value of 70. This is because the teacher has not been maximal in guiding students, has not been able to create students 'interest in learning and is weak in attracting students' attention to listening to material explanations.

At the time of learning students are less interested in learning so that students make noise, chat with friends, and do not pay attention to ongoing learning, because teachers still apply the learning model that is still teacher-centered (Teaching Center). Another factor is the lack of use of technology-based learning media in teaching so that it becomes difficult to understand, other than that students lack intensive training, students still rely on group mates, lack of seriousness and perseverance of students following the learning process, so students feel difficulties in solving problems Indonesian language with the constraints that have been described, then students feel bored and not eager to take lessons, lack of desire to know, and not care about the value obtained. In various problems that occur in the field, the teacher's role and attention is needed to improve the situation to be better through learning models and supporting learning media.

Everything that can help the teaching and learning process can be used as a learning medium. The use of technology in this case means that facilitates the continuation of the world of education. Technology makes it easy to deliver learning material to students. Utilizing technology as an educational support tool is an effort to improve teacher professionalism and student learning outcomes.

By seeing the fact above, the researcher will do an action to give the influence for the problem by changing the learning situation and involve active student, think critically, creative, and can push the student to develop courage in giving argument and ability in working together in solving a problem in the learning process. One of the Learning Models Flash Media to create the learning process to student-centered (student oriented) one of that is learning model Cooperative Intergrated Reading and Composition (CIRC) with the media flash. 


\section{Methodology}

The type of research used in this study is a quasi-experimental research using nonequivalent control group design. Nonequivalent quantitative control group design research is a study that compares the pretest and posttest values between the experimental class and the control class. [1]. [2] added "If the subject is less than 100 people, all samples are taken. Furthermore, if the subject is more than 100, then the sample can be taken from $10-15 \%$ or 20 $25 \%$ or more. "The population of this study were all fifth-grade students of Public Primary School 101776 Sampali 2017/2018 Academic Year which consisted of 50 students.

Table 1. The number of grade V students Public Primary School 101776 Sampali

\begin{tabular}{cc} 
Class & $\begin{array}{c}\text { The number of } \\
\text { students }\end{array}$ \\
\hline V-A (Control Class) & 25 \\
V-B (Experiment & 25 \\
Class) & 50 Student \\
\hline
\end{tabular}

\section{Result and Discussion}

The Meaning Of Learning according to [3] states "learning is a business process carried out by a person to obtain a new behavior change as a whole, as a result of his own experience in interaction with his environment". The purpose of trying is in the form of activities, so learning is an activity carried out by learners that is done intentionally so that there is a change in the ability of individual learners from those who do not know to know and from those who do not understand to understand. Furthermore, [4] state that the characteristics of learning, namely: (1) the learning process must experience, act, react and transcend. (2) through a variety of experiences and subjects centered on a particular goal. (3) meaningful to certain lives. (4) sourced from needs and goals that encourage equilibrium motivation. (5) influenced by nature and environment. (6) influenced by individual differences. (7) take place effectively if the desired experiences and results are in accordance with your maturity as students. (8) the best learning process is if you know the status and progress. (9) functional unity of various procedures.

Learning outcomes are influenced by cognitive where students' attitudes in undergoing the learning process, and affective namely student interest in working on the direction that the teacher conveyed to the learning process and psychomotory related to student skills. [5] says that in terms of results, the learning process is said to be successful if there is a positive behavior change in the students as a whole or most $(75 \%)$, so an indicator that makes it a benchmark in stating that a learning process can said to be successful, based on the provisions of the enhanced curriculum that is currently used is covering the following: (1) a minimum of $75 \%$ of the contents and principles of learning can be understood, accepted and applied by students and teachers in the classroom. (2) a minimum of $75 \%$ of students feel they have the ease, enjoyment and high willingness to learn. (3) students participate actively in the learning process. (4) material that is communicated according to the needs of students and they 
consider that it will be very useful for their future lives. (5) the learning that is developed can foster students' interest in learning to learn more.

So, from the explanation above, it can be concluded that the learning outcomes are the abilities that students get both in terms of cognitive, affective and psychomotor aspects obtained through learning experiences and influenced by internal and external factors of individual learners. The learning process certainly involves a variety of factors that are very complex, because every individual who learns must occur because of the impulse from within himself, as well as the impulse from outside himself. Therefore, each factor needs to be considered so that the learning process can succeed in accordance with the stated goals. According to [6], the factors that influence learning are: 1) internal factors (factors within students), namely the physical / spiritual condition/ condition of students; 2) external factors (external factors of students), namely environmental conditions around students; 3) learning approach factors (approach to learning), namely the type of student learning efforts that include strategies and methods used by students to study the subject matter.

Language skills have four components that influence each other. The four components are listening, speaking, reading and writing. These four language skills can be obtained by training properly and correctly. The language skills consist of interrelated productive and receptive skills, these four skills according to [7] are: (1) listening skill is the skill to understand and interpret messages delivered orally by others. (2) speaking skills are the skills to convey messages orally to others. (3) reading skills are skills to understand and interpret messages delivered in writing by others. (4) writing skills are the skills to convey messages to other parties in writing.

Linguistic learning in primary schools is integrated in language skills, such as listening, speaking, reading, and writing. These four aspects are integrated when learning must be provided in a balanced and integrated way to achieve the objectives of learning Indonesian language that has been included in the competency standards of the Indonesian Primary School language subjects. Learning model is a benchmark for achieving learning objectives, because learning models can determine the learning process that takes place. Of course, you must pay attention to the characteristics of subjects so that they are appropriate to be applied to one of the learning models. Understanding the learning model according to [8], "learning models are patterns that are used as guidelines in planning learning in class / tutorial". A pattern used as a guide for planning learning in the classroom to determine learning devices. Cooperative learning is learning that refers to learning methods where students work together in small groups and help each other in learning. In cooperative learning generally involves groups consisting of 4 students with different abilities and different sizes. One type of cooperative learning is CIRC (Cooperative Integrated Reading and Composition) which specifically teaches reading and writing techniques at the primary and secondary school level. According to [9] said that "CIRC is an integrated composition of reading and writing cooperatively in groups. The syntax is to form a heterogeneous group of 4 people, in this group not distinguished by gender, ethnicity / nation, or level of intelligence of students. and in this group, there should be students who are smart, moderate, or weak, and each student should feel suitable for each other. With group learning, it is hoped that students can improve their critical, creative, and fostering a high sense of social. Before a group is formed, students are taught how to work together in a group. Students are taught to be good listeners, can explain to friends in groups, discuss, encourage other friends to work together, respect the opinions of other friends, and so on. The advantages of the CIRC model according to is [10] : (1) improve students' skills in solving problem solving problems, because students are given prose texts as illustrations to facilitate students in expressing ideas. (2) teacher dominance in 
learning is reduced, because in this learning emphasizes student activity. (3) students are motivated by results carefully, because in the group concerned with the role of each individual to work. (4) students can understand the meaning of the question and check each other's work because students are given prose texts and asked to find the main themes and ideas for poetry. (5) helping weak students, in learning each individual helps each other so that the results achieved will be good. (6) improve learning outcomes, especially in solving problems in prose texts.

The implication of applying the CIRC learning model is one of which is the realization of a student-centered learning process that can train in building collaboration, critical thinking, respecting opinions and courage and will affect student learning outcomes.

In addition to the CIRC model, it is more innovative when combined with technology-based media where this media is in the form of games. Game means game, the term game according to its meaning is a particular situation or condition when someone is looking for pleasure or satisfaction through activities or activities. [11] "Educational games are learning media that can improve understanding quickly because they are supported by interesting games and children become active". So, it can be concluded that educational games are a computer game that contains educational material in the form of interactive games as a medium for learning and can improve understanding quickly. According to Susilana in his book Learning Media: Nature, Development, Utilization, and Assessment in general the learning media has uses, among others [12], as follows: (1) Clarifying the message so that it is not too verbalistic; (2) Overcoming the limitations of space, time, energy and sensory power; (3) Generating learning passion, more direct interaction between students and learning resources; (4) Allows children to learn independently according to their talent and visual auditor and kinesthetic abilities; (5) Give the same stimuli, equalize experiences and give rise to the same perception.

Educational learning in elementary school is learning that requires student activity (student active teaching), not teacheractive teaching. Learning orientation is not on the teacher (teacher centered) but student-centered. According to [13] "Macromedia Flash is a product of Macromedia, which is an animation-making program". Macromedia Flash is one of the popular programs in making animation, both for Web, presentation, game, or other purposes. There are several advantages of Macromedia Flash 8.0 according to [14]: (a) Can create interactive buttons with a movie or other object; (b) can make changes in color transparency in a movie, (c) can make changes in animation from one form to another; (d) can make animated movements by following the predetermined flow. (e) can be converted and published (Publish) into several types, including .swf, .html, .gif, .jpg, .png, .exe, .mov. (f) can process and create animations from Bitmap objects. Flash vector-assisted animation programs have flexibility in making vectors. Pretest is also called the initial ability test given to both classes at the beginning of the study carried out to find out the learning outcomes in the cognitive (Knowledge).

Based on the research data obtained the average value of pretest of students in the control class was 34.6 and in the experimental class before being given treatment, the average score of the students' pretest was 34. The average score of the pre-test results of students before being treated with the conventional model in the control class is 34.6 and the standard deviation is 8.40. While the average value of students before being treated with the Cooperative Integrated Reading and Composition model is 34.2 and the standard deviation is 9.31 . Thus, it can be concluded that the results of learning Indonesian students are still low before receiving treatment. After doing the pretest, it was known that students in the control class who received a score of 25 as many as 5 people, a value of 30 as many as 8 people, a score of 35 as many as 5 people, a value of 40 as many as 1 person, a value of 45 as many as 3 people, a value of 50 
as many as 3 people. Whereas in the experimental class that got a score of 25 as many as 8 people, a value of 30 as many as 7 people, a value of 35 as many as 1 person, a value of 40 as many as 2 people, a value of 45 as many as 4 people and a value of 50 as many as 3 people.

After obtaining the pretest data of students from the control and experimental classes, the next step is to test data analysis using a prerequisite test where the data requirements must be normally and homogeneously distributed. Before testing the hypothesis first the data prerequisite test is carried out, namely the normality test. Normality Test is done to find out whether the data taken from the population is normally distributed or not. In this study, researchers used the Liliefors test. Normality Test Results obtained in the control classLcount $=0,161$ andLtable $=0,173$ so it was concludedLcount $<$ Ltable $=0,167<0,173$ results of a pretest data control class proved that are normally distributed. While in experimental classLcount $=$ 0,154 and $\operatorname{Ltable}=0,173$ so it was concludedLcount $<$ Ltable $=0,154<0,173$ results of a pretest data experimental class proved that are normally distributed.

Homogeneity testing is done to find out whether the sample class comes from a homogeneous population or not, meaning that the sample used in this study can represent the entire population. Test results Homogeneity of data obtained valuesFcount $=1,228$ and Ftable $=1,983$ so it was concludedFcount $<$ Ftable $=1,228<1,983$ it means the sample used in this study is declared homogeneous or can represent the entire population. The t test (different test) pretest data was used to determine the similarity of students' initial abilities in the two sample groups. The results of different students' initial ability tests obtained that for the pretest valuetcount $<$ ttable $=0,16<2,01$ then $H o$ is accepted so it can be concluded that the initial ability of students in the control class is the same as the initial ability of students in the experimental class. After obtaining that the pretest data from both classes is normal, homogeneous and there is no specific difference, then in the case of this study the two sample classes were given different treatments. The difference in question is that the experimental class will be treated by applying the Cooperative Integrated Reading and Composition learning model assisted by flash media while in the control class the NHT (Number Head Together) learning model is treated.

After the two classes were given different treatments, all students in the two classes were then given a posttest with the same questions as the pretest. The results obtained showed that the mean value in the control class was 73 and the standard deviation was 9.24. While the average value of the experimental class students is 80.6 and the standard deviation is 10.3 . Thus, it can be concluded that the results of learning Indonesian language students are higher after receiving treatment. then the posttest result is known that students in the control class who get 60 scores of 4 people, a score of 65 as many as 5 people, a score of 70 as much as 2 people, a value of 75 as many as 6 people, a value of 80 as many as 3 people, a value of 85 as many as 4 people and a value of 90 as many as 1 person. Whereas in the experimental class that got a score of 60 as many as 3 people, a score of 65 as many as 5 people, a value of 75 as many as 3 people, a value of 80 as many as 4 people, a value of 85 as many as 8 people, a value of 90 as many as 5 people and a value of 95 as many as 1 person. So, the picture above shows that in the Experiment class, the grades obtained by students are better and higher than in the control class. This shows that the application of Indonesian language learning by using Cooperative Integrated Reading and Composition learning models assisted by flash media is good to be applied in learning activities.

Before testing the hypothesis on the posttest data, the data pre-requisite test is normality using the Liliefors test. The results of the normality test obtained in the control classLcount= 0,167 and Ltable $=0,173$ so it can be concluded thatLcount $<$ Ltable $=0,167<0,173$ the data prove that the results of the control class postestare normally distributed. While in 
experimental classLcount $=0,150$ and $\mathrm{Ltable}=0,173 \mathrm{so}$ it can be concluded thatLcount $<$ Ltable $=0,150<0,173$ the data prove that the results of the experimental class postestare normally distributed. Homogeneity testing is done to find out whether the sample class comes from a homogeneous population or not, in the sense that the sample used in this study can represent the entire population. The results of the data homogeneity test obtained in the control class value Fcount $=1,178$ and Ftable $=1,983$ so it can be concluded that Fcount $<$ Ftable is $1,178<1,983$ which means that the sample used in this study is declared homogeneous or can represent the entire population.

Hypothesis testing in this study is there is a significant and positive influence on the use of Cooperative Integrated Reading and Composition learning models assisted by flash media on student learning outcomes in Indonesian language lessons more effectively when compared to Number Head Together learning models. To test the hypothesis, the step taken is to analyze the results of the t-test. The hypothesis criteria will be accepted if tcount is greater than ttable at a significance level of $5 \%$, and the significance is less than 0.05 , it can be concluded that the hypothesis in this study is accepted. The results of testing hypotheses obtained the value of Posttest tcount $>$ ttable is $3,317>2,012$ so Ho is rejected and $\mathrm{Ha}$ is accepted, so it can be concluded that there is a significant influence by using Cooperative Integrated reading and Composition learning model assisted by flash media on the learning outcomes of Indonesian students of Grade V State Primary School 101776 Sampali sub-district Percut Sei Tuan.

\section{Conclusion}

Based on the data obtained from the research and data processing, the following conclusions can be drawn:

a) The average value of student learning outcomes in the control class given the learning model Number Heaad Together Indonesian Language Class V-A Public Primary School 101776 Sampali District Percut Sei Tuan 2017/2018 is 73.

b) The average value of student learning outcomes in the experimental class which was treated using the Cooperative Integrated Reading and Composition Learning Model assisted by flash media on the learning outcomes of Indonesian in class V-B Public Primary School 101776 Sampali Subdistrict Percut Sei Tuan 2017/2018 is 80, 6 .

c) Based on the results of the calculation of the t-test with the provisions of the posttest value, tcount $>$ ttable, the results obtained from the acquisition of posttest scores are tcount $=3.317$ while ttable $=2.012$. With this $3,317>2,012$, Ho is rejected and $\mathrm{Ha}$ is accepted, that there is an influence of the use of Cooperative Integrated Reading and Composition Learning Model assisted by flash media on the learning outcomes of Indonesian Language for students in grade V Public Primary School 101776 Sampali, Percut Sei Tuan 2017/2018.

\section{SUGGESTION}

Based on the results and conclusions above, the researcher presents several suggestions including:

(1) For Indonesian Language subject teachers (Class Teachers) it is better to use learning models such as Cooperative Integrated Reading and Composition (CIRC) assisted by 
flash media, because by using this learning model in Indonesian language learning students tend to be more eager and active to learn delivered and that will affect the learning outcomes.

(2) The importance of learning various types of learning models that are suitable for teachers to use in the learning process, and the development of technology-based media for that also requires further research for other researchers as concrete steps to improve student learning outcomes and even increase students' enthusiasm and enthusiasm. in learning both for all subjects.

(3) The education manager is advised to provide a wide opportunity for teachers to make changes in learning activities through official programs in an effort to increase students' enthusiasm and participation in learning.

(4) Given the limitations of researchers, the researchers suggest that other researchers who want to research in the same form of research are advised to conduct research on different locations and materials so that it can be used as a comparative study of teachers in improving the quality of education, especially in Indonesian subjects.

\section{References}

[1] Sugiyono, Metode Penelitian Pendidikan. Bandung: Alfabeta, 2013.

[2] S. Arikunto, Manajemen Penelitian. Jakarta: Rineka Cipta, 2010.

[3] Slameto, Belajar dan Faktor-Faktor yang Mempengruhinya. Jakarta: Rineka Cipta, 2015.

[4] Jihad \& Haris, Evaluasi Pembelajaran. Yogyakarta: Multi Presindo, 2013.

[5] E. Mulyasa, Menjadi Guru Profesional. Bandung: Remaja Rosdakarya, 2011.

[6] M. Syah, Psikologi Pendidikan. Jakarta: Rajawali Pers, 2012.

[7] Solhan, Pendidikan Bahasa Indonesia di SD. Jakarta: Universitas Terbuka, 2008.

[8] A. Suprijono, Cooperative Learning. Yogyakarta: Pustaka Pelajar, 2010.

[9] Ngalimun, Strategi dan Model Pembelajaran. Yogyakarta: Aswaja Pressindo, 2016.

[10] Suyatno, Menjelajah Pembelajaran Inovatif. Sidoarjo: Masmedia Buana Pustaka, 2009.

[11] Wijayanto \& Istianah, "Pengaruh Penggunaan Media Game Edukasi Terhadap Hasil Belajar IPA Siswa Kelas IV SDN Kajartengguli Prambon Sidoarjo,” JPGSD, vol. 5, no. 3, p. 338, 2017.

[12] R. et al Susilana, Media Pembelajaran. Bandung: Wacana Prima, 2009.

[13] Z. Fanani, Tip dan Trik Animasi Macromedia Flash Menyingkap Rahasia Teknik Animasi. Jakarta: Graha Ilmu, 2006.

[14] B. Suryati \& Agung, "Pengembangan Media Pembelajaran Interaktif Berbantuan Macromedia Flash 8.0 Pada Mata Pelajaran Matematika Kelas Iii Sd N Tegalrejo 2 Tahun Ajaran 2016/2017," PGSD J., vol. 3, no. 1, 2017. 